\title{
SISTEM INFORMASI MANAJEMAN DATA SISWA PADA YAYASAN SUARA ALAM KABUPATEN KUBU RAYA BERBASIS WEBSITE
}

\author{
Wanty Eka Jayanti[1]; Yoki Firmansyah ${ }^{[2]}$, Maria Goretti Yuni ${ }^{[3]}$ \\ Program Studi Sistem Informasi[1] [2] [3] \\ Universitas Bina Sarana Informatika \\ wanty.wej@bsi.ac.id ; yoki.yry@bsi.ac.id ; mariagoreti@gmail.com
}

\begin{tabular}{ll}
\hline INFO ARTIKEL & INTISARI \\
\hline Diajukan : & Selain pesatnya perkembangan internet sebagai alat komunikasi, juga \\
03 Juli 2021 & mempermudah akses informasi oleh lembaga pendidikan. Sebelum \\
Diterima : & munculnya Internet, proses transmisi informasi ini tidak bekerja dengan \\
25 Juli 2021 & baik, efisien dan efektif. Karena website memiliki sistem monitoring \\
Diterbitkan: & informasi pada Yayasan Suara Alam Kabupaten Kubu Raya, dapat memberi \\
01 Desember 2021 & kemudahan bagi orang tua siswa untuk pemaantauan akademik siswa \\
& disekolah yang meliputi absensi dan nilai akademik siswa sehingga \\
Kata Kunci : & informasi yang diberikan sekolah dapat diterima dengan baik bagi siswa \\
manajemen data, sistem & dan orang tua Sistem dikembangkan menggunakan metode System \\
informasi, website & Development Cycle (SDLC) dengan model proses cascade. Perancangan \\
& sistem menggunakan Balsmiq Mockups sebagai alat perancangan \\
& antarmuka pengguna, Apache sebagai server dan Mysql sebagai alat \\
& penyimpanan dan pengelolaan data. Tujuan dari penelitian ini adalah \\
& untuk mengembangkan sistem informasi pelacakan siswa yang dapat \\
& diakses kapan saja, di mana saja untuk memantau perkembangan anak \\
& secara real time. Berdasarkan hasil pengolahan data pada proses \\
& pendataan, maka telah dikembangkan sistem informasi monitoring \\
penelitian dengan harapan sistem ini dapat mengontrol penuh proses & monitoring penelitian di masa yang akan datang.
\end{tabular}

\section{PENDAHULUAN}

Perkembangan teknologi informasi memudahkan segala aspek pekerjaan, ada banyak sistem informasi yang memudahkan pekerjaan tidak hanya dalam dunia pendidikan, tetapi juga dalam

dunia pendidikan, salah satunya yang paling bermanfaat adalah pendidikan. sistem informasi pemantauan adalah sekolah dasar ( SD). Yayasan Suara Alam Kegiatan akademik merupakan suatu siklus kegiatan belajar mengajar yang dilakukan dalam dunia pendidikan menurut (Fadjar, 2002) Pendidikan adalah suatu keadaan dimana orangorang saling berbagi dan menerima ide, konsep dan informasi serta menggalinya secara jujur, terbuka dan mandiri. Oleh karena itu, sekolah memegang peranan penting dalam kegiatan akademik dalam proses kegiatan akademik untuk mencapai tujuan pendidikan. Pencapaian suatu tujuan pendidikan memerlukan bimbingan dari pihak-pihak yang terlibat dalam kegiatan ilmiah, termasuk pemantauan. Pemantauan didefinisikan sebagai pengumpulan, evaluasi, dan penyebaran informasi yang sistematis tentang suatu proyek atau kegiatan yang sering digunakan untuk memverifikasi pencapaian tujuan dan untuk memastikan kepatuhan terhadap peraturan. (Hidayatullah, 2015). Stichting Suara Alam adalah lembaga pendidikan yang menyelenggarakan lembaga pendidikan Dasar (SD) dan Kleuterschool (TK). Sifatnya masih Ketika dijalankan secara manual, ketika sekolah hanya menggunakan aplikasi pendataan Microsoft Excel, sistem tidak dapat secara otomatis mengelola data jika data aplikasi masih salah. Selain itu, laporan ilmiah memakan waktu lama dan sulit digunakan dengan data ilmiah lokal. Masalah kedua adalah kurangnya komunikasi antara sekolah dan orang tua, dan orang tua biasanya tidak mengetahui perkembangan anak di sekolah. Masalah kedua, banyak orang tua bertanya tentang hasil belajar siswa melalui pesan singkat pribadi kepada kepala sekolah atau gurunya. Masalah ketiga adalah sulitnya orang tua menilai kehadiran dan kehadiran siswa. Jika Anda memiliki pertanyaan, hubungi kami untuk informasi beasiswa (SPP) atau untuk mengetahui lebih lanjut tentang rincian beasiswa SPP. Hal ini menyulitkan orang tua untuk memantau data tersebut, karena orang tua harus pergi ke sekolah terlebih dahulu untuk mendapatkan informasi tentang biaya sekolah. 
Berdasarkan interpretasi permasalahan tersebut di atas, maka perlu diusulkan pengembangan sistem informasi monitoring siswa pada Yayasan Swara Alam Kabupaten Kuba Raya berdasarkan kebutuhan untuk mencari solusi.

\section{BAHAN DAN METODE}

Dalam penelitian ini, peneliti harus menerapkan metode penelitian. Penelitian kualitatif adalah metode mempelajari situasi, objek, situasi, pola berpikir dan pelajaran saat ini yang dipelajari oleh sekelompok orang. (Sugiyono, 2015) Peneliti juga menggunakan metode pengembangan perangkat lunak dan teknik pemulihan data. Berikut penjelasannya.

A. Metode Pengembangan Perangkat Lunak

Analisis; Membentuk; Voting Test dan langkah- langkah dukungan Metode waterfall adalah metode yang digunakan untuk mengembangkan program dengan menggunakan desain waterfall. Model input mendukung siklus hidup perangkat lunak yang berkelanjutan atau tidak terputus dalam model pengembangan perangkat lunak (Shalahuddin \& Sukamto, 2018) yaitu :

Adapun tahapan dalam pengembangan perangkat

1. Pengumpulan Kebutuhan(Analysis)

Pada tahap pengumpulan data ini, peneliti bertemu langsung dengan pihak Yayasan Suara Alam untuk mendengar langsung kendala menyampaikan informasi kepada orang tua siswa.

2. Rancagan Desain atau Perancagan

Tahapan ini, peneliti melakukan peracangan struktur data yang peneliti gambarkan dengan menggunakan model ERD (Entity Relationship Diagram) dan LRS (Logical Record Structure). Untuk mendesain database dengan UML (Unifed Modeling Language) diagram yaitu terdiri dari: Use Case Diagram, Activity Diagram. Sequence Diagram, Class Diagram.

3. Pembuatan Kode Programam

Pada tahapan ini, peneliti mulai mengimplementasikan desain rancangan sistem ke dalam program aplikasi perangkat lunak, yang dimana saling berhubungan antara pemilihan perangkat keras dan penyusunan perangkat lunak aplikasi. Dalam pengerjaan program, peneliti menggunakan aplikasi Balsamiq Wireframes sebagai media pembuatan desain mockup dan MySql sebagai media untuk menampung dan mengolahdatabase.
B. Teknik Pengumpulan Data

Dalam penelitian ini, peneliti menggunakan teknik dalam mengumpulkan data, beberapa proses teknik pengumpulan data yang dilakukan adalah sebagai berikut [2]:

1. Observasi

Kegiatatan observasi dilakukan di Yayasan Suara Alam pada Kepala Sekolah dan Wali Kelas yang merupakan bagian pengelola data akademik siswa. Website sekolah membuat review tentang lokasi sekolah, kondisi sekolah, rencana layanan sekolah kepada orang tua siswa, dan permasalahan yang mungkin timbul dari pihak sekolah. Pikirkan solusi untuk masalah yang Anda hadapi di sekolah SD Yayasan Suara Alam.

2. Wawancara

Wawancara dilakukan untuk memperoleh informasi yang lengkap dan peneliti mengajukan pertanyaan dan jawaban tentang semua kegiatan yang berhubungan dengan studi konseling. Debbie Sawanto telah ditunjuk sebagai CEO SPD Yayasan Suwara Al. Baca hasil wawancara SD Yayasan Suara Alam terdapat beberapa permasalahan yang ada saat ini.

3. Studi Pustaka

Studi pustaka dilakukan dengan cara membaca dan mempelajari buku-buku yang berhubungan dengan topik penelitian yang dibahas serta mengumpulkan data dari buku-buku referensi, catatan yang diperoleh peneliti selama masa perkuliahan dalam penyusunan penelitian serta mengunjungi (browsing) situs-situs internet yang berhubungan dengan skripsi peneliti. Studi kepustakaan bukan hanya buku saja tapi juga bisa diambil dari jurnal penelitian sebelumnya

\section{HASIL DAN PEMBAHASAN}

Setelah Peneliti melakukan observasi untuk mempelajari sistem berjalan pada Sekolah Dasar Yayasan Suara Alam Kubu Raya,terdapat beberapa permasalahan yang sering terjadi yaitu sulitnya guru dalam merekap data absensi siswa, staf TU dalam melihat data administrasi siswa, dan wali kelas untuk merekap data penilaian siswa serta orangtua untuk melihat perkembangan anaknya. Keluhan yang ada saat ini ialah kurang efisiennya jika harus melihat satu persatu dari awal pendataan dan jika orang tua ingin mengetahui infomasi mengenai anak harus 
datang ke sekolah. Hal ini tentu menjadi masalah karena memperlambat pekerjaan dan lambatnya untuk mengetahui informasi yang berhubungan dengan siswa dan administrasi sekolah.

Solusi yang ditawarkan kepada Sekolah Dasar Yayasan Suara Alam Kubu Raya berupa usulan sistem aplikasi berbasis website yang membantu siswa dan orang tua siswa serta pihak sekolah khususnya operator sekolah, TU, dan Kepala Sekolah untuk melihat secara kesuluruhan data absensi kehadiran siswa, penilaian siswa, dan pembayaran siswa. Dimana data tersebut diambil dari database sekolah, kemudian bagian operator sekolah dapat mengolah data yang ada di website tersebut dan pihak lain dapat mengaksesnya. Selain itu website bisa dilihat dimanapun dan kapanpun karena bisa diakses melalui internet.

\section{Kebutuhan Pengguna}

Pada tahap ini, peneliti mengevaluasi persyaratan proses untuk meningkatkan data pengguna. Dalam penelitian ini terdapat dua pengguna yang saling berinteraksi yaitu bagian Operator Sekolah sebagai admin, dan guru, orangtua serta Tata Usaha sebagai

1. Operator Sekolah sebagai Admin
a. Admin mengelola data siswa
b. Admin mengolah data kelas
c. Admin mengolah data mata pelajaran
d. Admin mengolah data guru
e. Admin mengolah data Tata Usaha
f. Admin mengolah data orang tua

2. Skenario Kebutuhan Orang Tua
a. Orang Tua melihat absensi kehadiran siswa
b. Orang Tua melihat nilai siswa (Ulangan Harian, Ujian Tengah Semester dan Ujian Akhir Semester).
c. Orang Tua melihat data pembayaran siswa (SPP)

3. Kebutuhan Sistem

a. Sistem melakukan rekap data absensi, penilaian dan pembayaran administrasi siswa pada bulan tersebut.

b. Mengolah data target pencapaian absensi siswa, penilaian siswa, dan pembayaran yang sudah maupun belum dicapai setiap bulan.

c. Semua pengguna baik operator sekolah (admin) maupun user (pengguna) harus melakukan login saat masuk ke website dan melakukan logout jika telah selesai menggunakan website.

\section{Rancangan Activity Diagram}

Berikut adalah activity diagram rancangan sistem:

a. Diagram Aktivitas Nilai Siswa
Berikut adalah activity diagram rancangan sistem:

1. Diagram Aktivitas Nilai Siswa

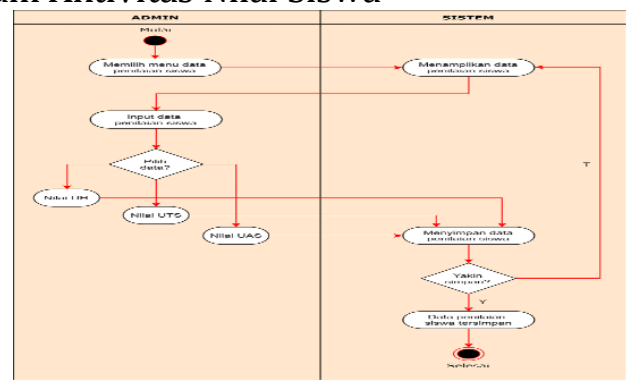

Sumber : Penelitian (2021)

Gambar 1

Diagram Aktivitas Pengolahan Data Nilai Siswa

2. Aktivity Diagram Pembayran Siswa

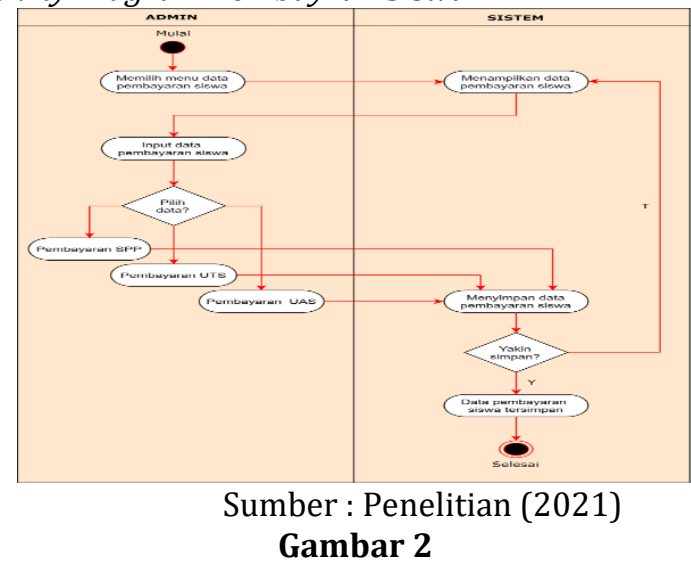

Diagram Aktivitas Pembayaran Siswa

3. Activity Diagram Pengolahan Data Absensi Siswa

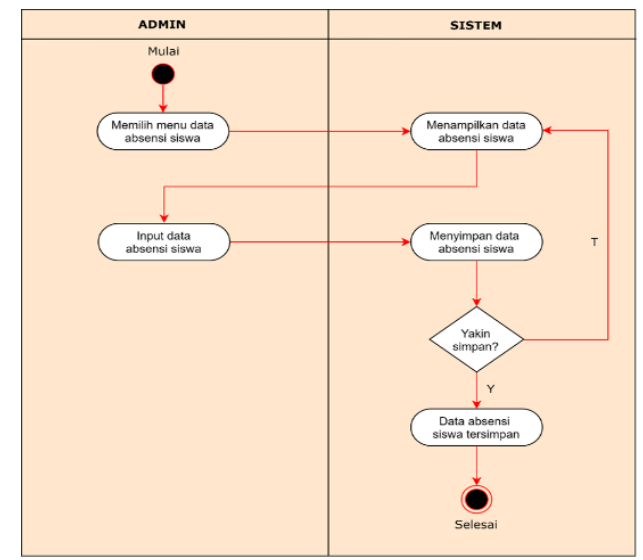

Sumber : Penelitian (2021)

Gambar 3

Diagram Aktivitas Pengolahan Data Absensi Siswa

\section{Activity Diagram Pengolahan Data} Master 


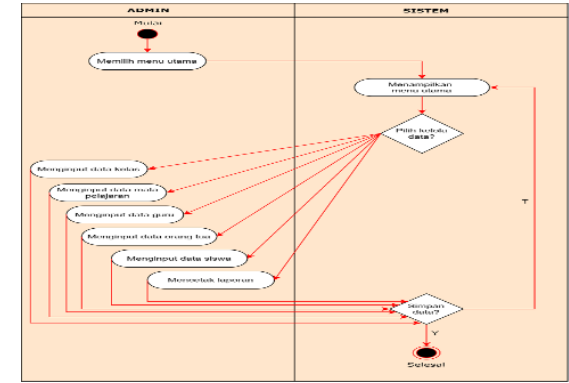

Sumber : Penelitian (2021) Gambar 4

DiagramAktivitas Pengolahan Data Master

\section{Activity Diagram Menampilkan Data} Absensi Siswa

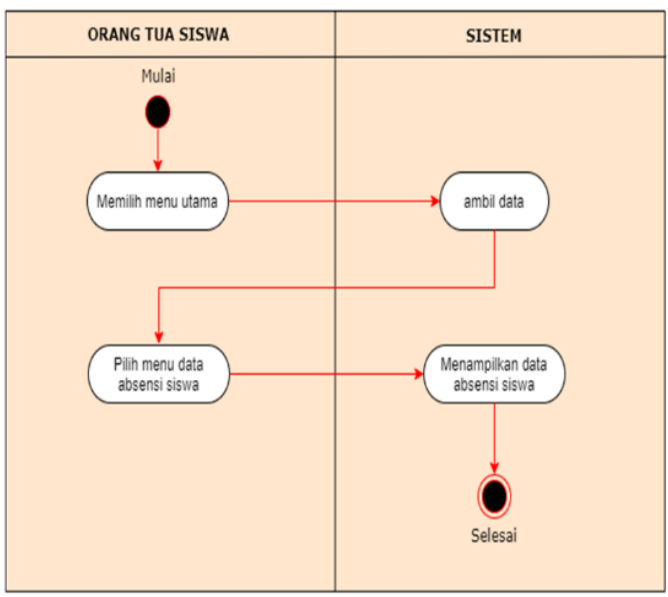

Sumber : Penelitian (2021)

Gambar 5

DiagramAktivitas Menampilkan Data Absensi Siswa

6. Activity Diagram Menampilkan Data Pembayaran Siswa

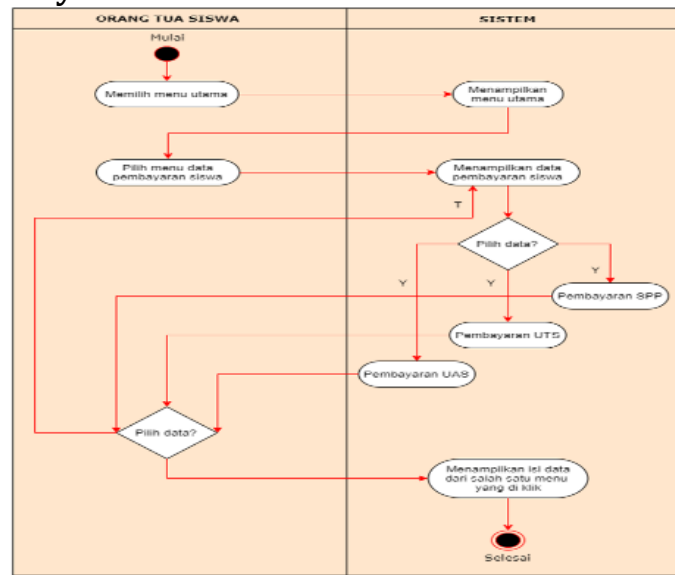

Sumber : Penelitian (2021)

Gambar 6

Diagram Aktivitas Cetak Laporan

7. Activity Diagram Cetak Laporan

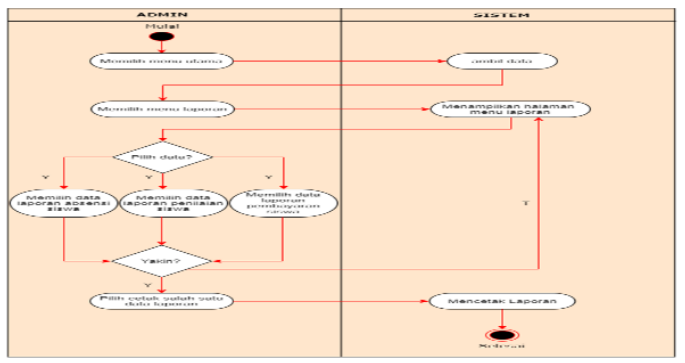

Sumber : Penelitian (2021)

Gambar 7

Diagram Aktivitas Cetak Laporan

\section{Rancangan Antarmuka}

1. Tampilan Halaman Login Orang Tua Siswa

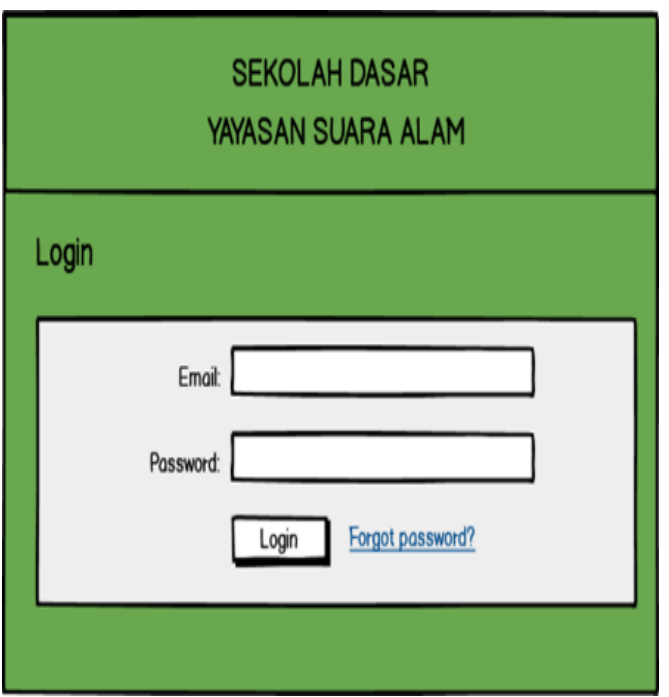

Sumber : Hasil Pengolahan (2021)

Gambar 8

Tampilan Halaman Login Orang Tua Siswa

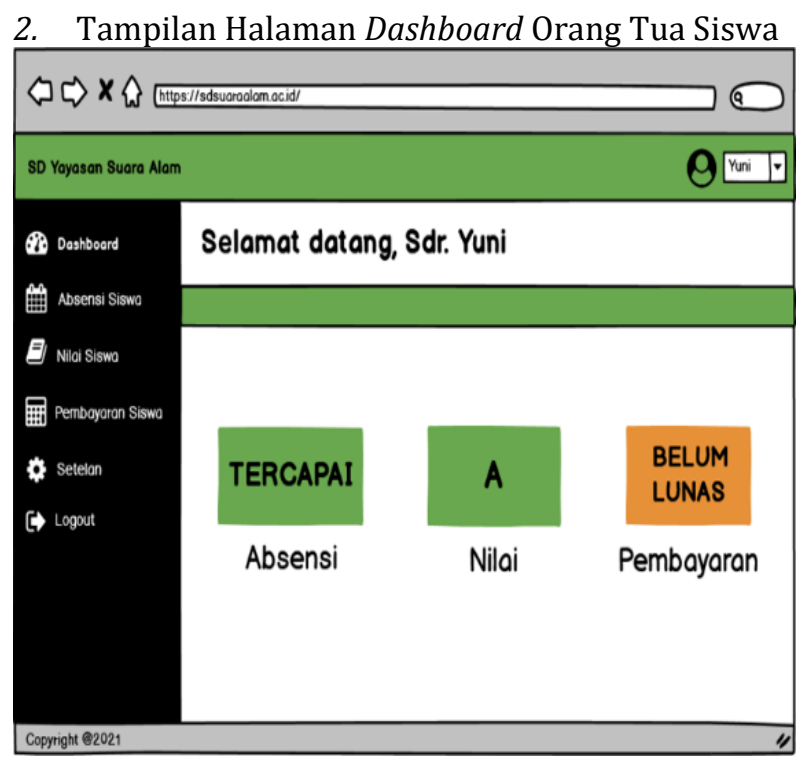

Sumber : Hasil Pengolahan (2021) Gambar 9 
JURNAL KHATULISTIWA INFORMATIKA p-ISSN: 2339-1928 e-ISSN: 2579-633X

\begin{tabular}{|c|c|c|c|c|c|}
\hline \multicolumn{6}{|c|}{ 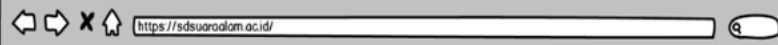 } \\
\hline \multicolumn{5}{|l|}{ SO Yeysason Suaro Alom } & Orumit. \\
\hline \multirow{4}{*}{ 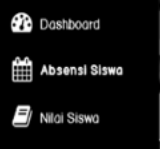 } & \multicolumn{5}{|c|}{ Dosthoord | Absensi ismo } \\
\hline & & & & & GCort \\
\hline & \multicolumn{4}{|c|}{ Doto Absensisisiswo } & Shlow 5 国 entives \\
\hline & No lordik & Vama Sismo & Bulan & Juman Absens & Pencepolon (Mn 22) \\
\hline \multirow{3}{*}{ 眮 Pemboyaran Siswo } & 223456 & Evuno & Jui & 24 & Tercope \\
\hline & 123456 & Evuno & Agustus & 22 & Tercepa \\
\hline & 223456 & Guro & Septenterer & 21 & Trak Tercapal \\
\hline \multirow[t]{2}{*}{ Et Logout } & 23456 & Guno & Oknober & 24 & Tercopal \\
\hline & 22456 & Guro & Novenber & 23 & Tescepai \\
\hline
\end{tabular}

Sumber : Hasil Pengolahan (2021) Gambar 10

Tampilan Halaman Absensi Siswa

4. Tampilan Halaman Nilai Siswa

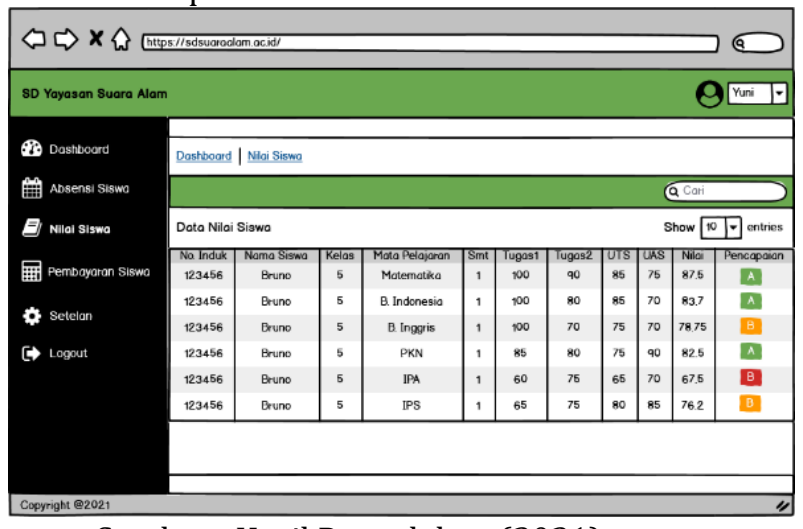

Sumber : Hasil Pengolahan (2021)

Gambar 11

Tampilan Halaman Nilai Siswa

5. Tampilan Halaman Pembayaran Siswa

\begin{tabular}{|c|c|c|c|c|c|c|}
\hline \multicolumn{6}{|c|}{ 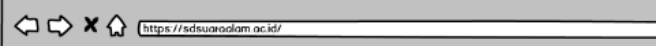 } & $\square$ \\
\hline \multicolumn{6}{|l|}{ so Yayasan Suara Alam } & 9Yuri \\
\hline \multirow{3}{*}{$\begin{array}{l}\text { Dashboard } \\
\text { Absensi Siswa } \\
\text { E Nilai Siswa }\end{array}$} & \multicolumn{6}{|c|}{ 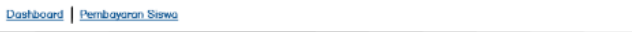 } \\
\hline & & & & & & Q Cari \\
\hline & \multicolumn{5}{|c|}{ Stotus Pembayaran Siswo } & Show 10 - entries \\
\hline \multirow{2}{*}{ 圆 Pemboyaran siswo } & Na Inouk & Noma Siew & Jens Pembayoran & Semeste & Tongagi Pembayaron & Stadus Pembogroren \\
\hline & 123456 & Erumo & spp & 1 & 20/06/2021 & Beumi Lunas \\
\hline \multirow{2}{*}{ \# setelan } & 123456 & Bruno & spp & 1 & $20 / 05 / 2021$ & Luran \\
\hline & 123456 & Brumo & SPP & ' & 20104/2021 & Lunass \\
\hline \multirow[t]{3}{*}{ [t) Logout } & 123456 & Burno & SPP & , & 20/03/2021 & Lunas \\
\hline & 123456 & Brumo & spp & 1 & 20102/2021 & Lunoss \\
\hline & 123466 & Brumo & spp & 1 & $20 / 01 / 2021$ & Lunoss \\
\hline
\end{tabular}

Sumber : Hasil Pengolahan (2021) Gambar 12

Tampilan Halaman Pembayaran Siswa

\section{Tampilan Halaman Setelan Siswa}

VOL. 9 NO. 2 Desember 2021

Halaman : 141-148

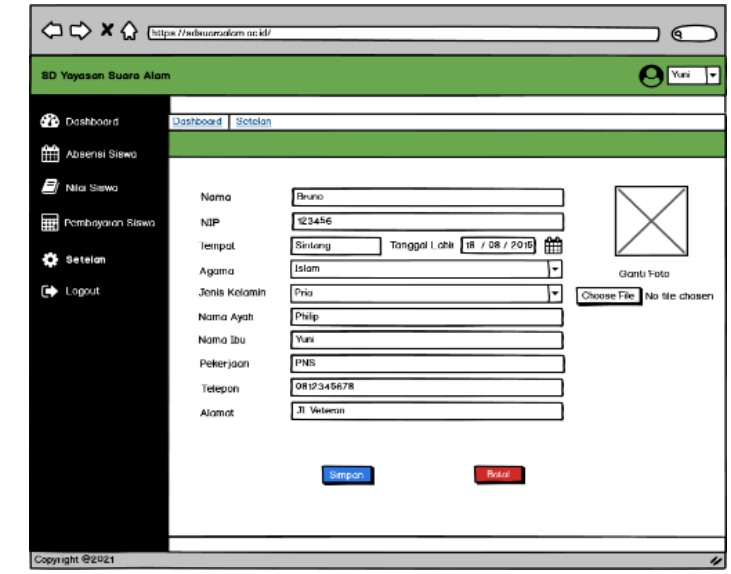

Sumber : Hasil Pengolahan (2021)

\section{Gambar 13}

7. Tampilan Halaman Login Admin

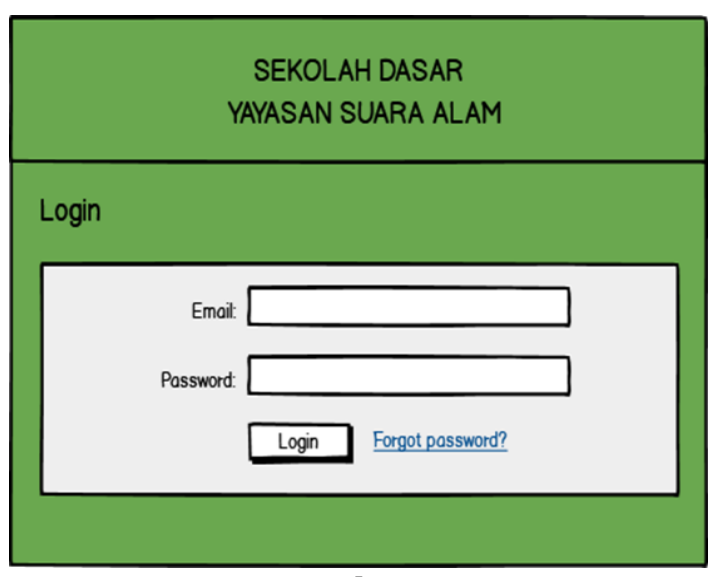

Gambar 14

Tampilan Halaman Login Admin

8. Tampilan Halaman Dashboard Admin

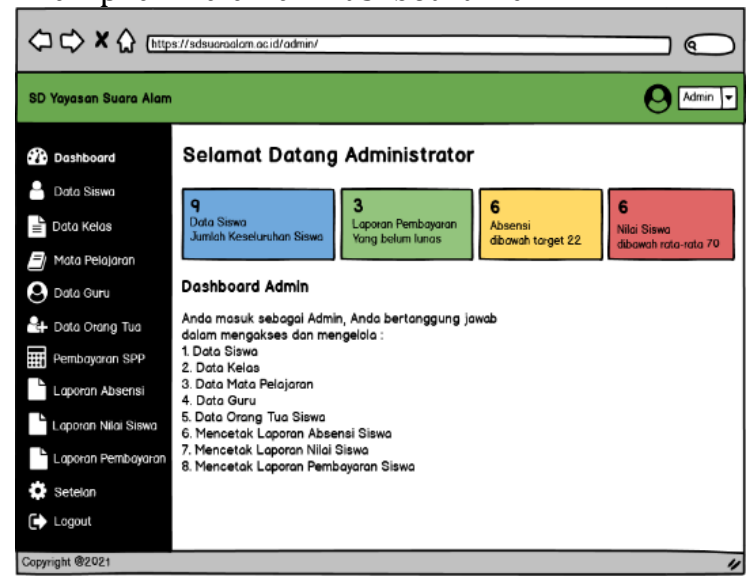

Sumber : Hasil Pengolahan (2021)

Gambar 15

Tampilan Halaman Dashboard Admin 
JURNAL KHATULISTIWA INFORMATIKA p-ISSN: 2339-1928 e-ISSN: 2579-633X

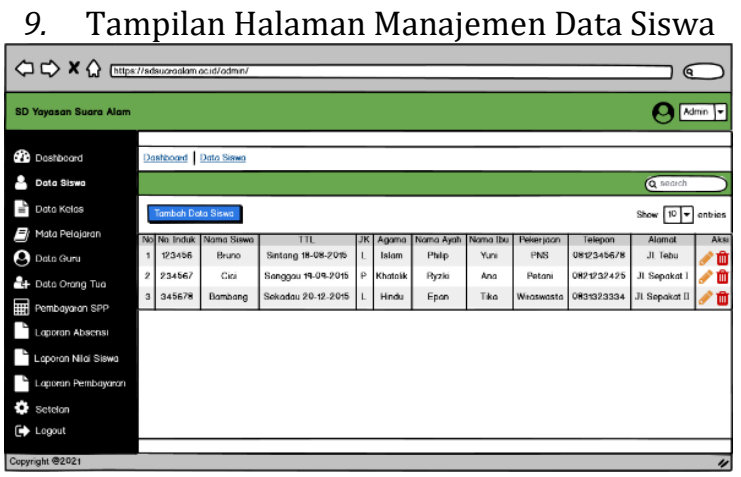

Sumber : Hasil Pengolahan (2021) Gambar 16

10. Tampilan Halaman Manajemen Data Kelas

\begin{tabular}{|c|c|c|c|c|}
\hline SD Yayasan Suara Alom & & & & (9) Admin \\
\hline 7) Dastboard & & a Kelas & & \\
\hline 3 Dato Siswa & & & & Q search \\
\hline Dato Kelas & & alas & & Show 100 entries \\
\hline E] Mota Pesajaran & N & Kelos & Tahur Angkction & Akst \\
\hline (9 Dato Quru & 1 & 3 & 2019 & 苗 \\
\hline it Dato Orang Tua & 2 & 4 & 2018 & 田 \\
\hline 侖 Pemboyoran spp & 3 & 5 & 2017 & 茴 \\
\hline L Laporan Absensi & & & & \\
\hline Laporan Nilai Siswo & & & & \\
\hline L Laporan Pemboyaran & & & & \\
\hline \% setelian & & & & \\
\hline 다 Logout & & & & \\
\hline Coppright $₫ 2021$ & & & & " \\
\hline
\end{tabular}

Sumber : Hasil Pengolahan (2021)

Gambar 17

Tampilan Halaman Data Kelas

11. Tampilan Halaman Data Mata Pelajaran

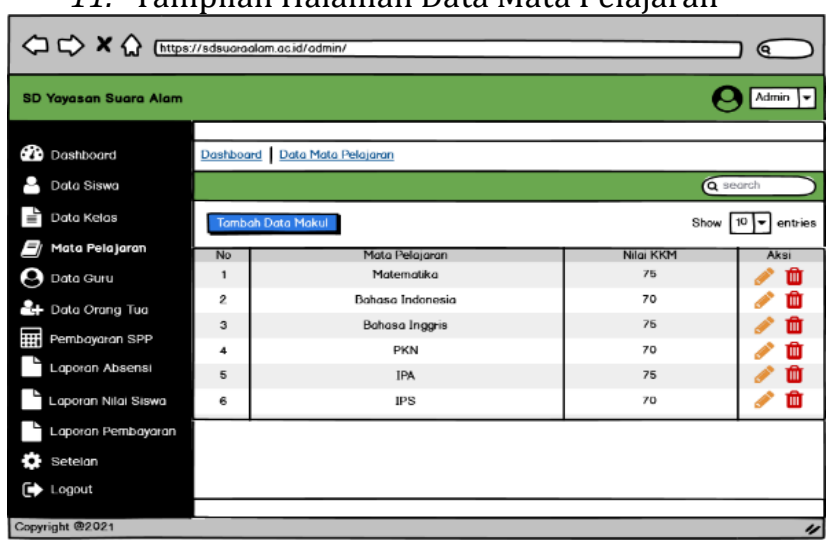

Sumber : Hasil Pengolahan (2021)

Gambar 18

Tampilan Halaman Data Mata Pelajaran
VOL. 9 NO. 2 Desember 2021

Halaman : 141-148

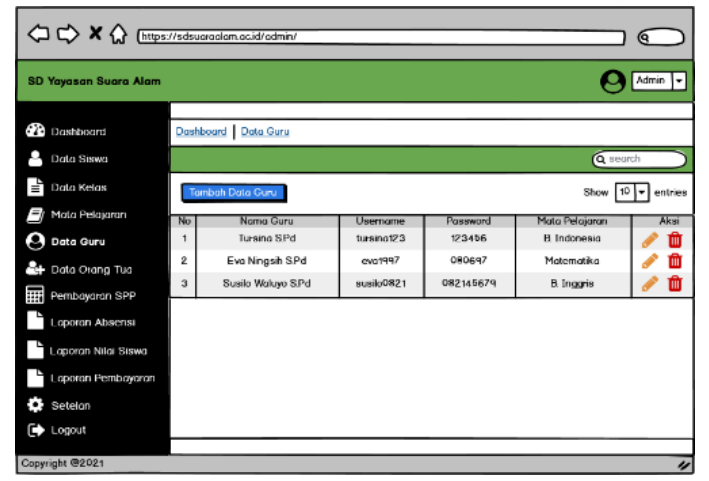

Sumber : Hasil Pengolahan (2021)

Gambar 19

Tampilan Halaman Data Guru

13. Tampilan Halaman Manajemen Data Orang Tua Siswa

\begin{tabular}{|c|c|c|c|c|c|c|}
\hline \multicolumn{7}{|c|}{ 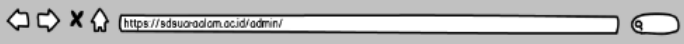 } \\
\hline \multicolumn{5}{|l|}{ SO Yayasan Suara Alam } & \multicolumn{2}{|c|}{ Q $\operatorname{Admin}$} \\
\hline (2) Dosthourd & \multicolumn{6}{|c|}{ 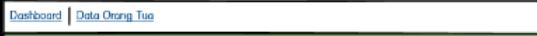 } \\
\hline (2) Doto Sisw & & & & & \multicolumn{2}{|c|}{ Q seconth } \\
\hline E Dato Keins & \multicolumn{4}{|c|}{ 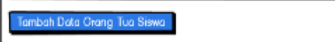 } & \multicolumn{2}{|c|}{ Show $D$ entres } \\
\hline E] Mato Pelopartin & No & Namo & Usemame & Passperd & Nomat & Nksi \\
\hline Q Dato Guru & 1 & Yuni & yunitzo & 12346678 & $\pi$ rew & 0 \\
\hline 24 Doto oreng twe & 2 & Evi Ningtros & evila9s & evining 7998 & Jl Sepakat 1 & t) \\
\hline 同 Pentogacen spp & 3 & Wollyo & whihyon:080 & walpuni88 & ת Sepokd II & 80 \\
\hline L' Laporon Absensi & & & & & & \\
\hline Leporan Nia Siswo & & & & & & \\
\hline 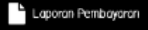 & & & & & & \\
\hline \$ Seteinn & & & & & & \\
\hline C) Logut & & & & & & \\
\hline Cagnght 12021 & & & & & & , \\
\hline
\end{tabular}

Sumber : Hasil Pengolahan (2021)

Gambar 20

Tampilan Halaman Data Orang Tua Siswa

14. Tampilan Halaman Manajemen Data Pembayaran SPP

\begin{tabular}{|c|c|c|c|c|c|c|}
\hline \multicolumn{7}{|l|}{ 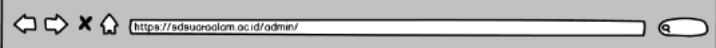 } \\
\hline \multicolumn{6}{|l|}{ SD Yayeson Suare Alom } & $9 \operatorname{simn}^{2}$ \\
\hline \multirow{11}{*}{ 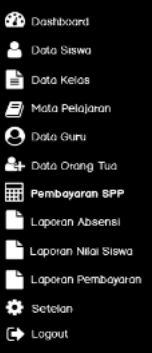 } & \multicolumn{6}{|c|}{ 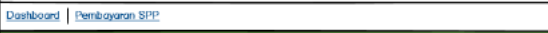 } \\
\hline & & Q इecerch \\
\hline & \multicolumn{5}{|c|}{ 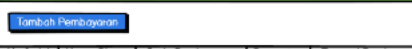 } & Show 100 entres \\
\hline & & & Hemosom & mentst & & 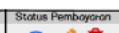 \\
\hline & ${ }^{223456}$ & Buno & spp & 1 & 20106/2021 & 00 \\
\hline & $\begin{array}{l}234567 \\
345678\end{array}$ & 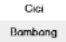 & $\begin{array}{l}\text { spp } \\
\text { spp }\end{array}$ & i & $\begin{array}{l}20 / 66 / 2021 \\
20106 / 2021\end{array}$ & -0 \\
\hline & & & & & & \\
\hline & & & & & & \\
\hline & & & & & & \\
\hline & & & & & & \\
\hline & & & & & & \\
\hline
\end{tabular}

Sumber : Hasil Pengolahan (2021)

Gambar 21

Tampilan Halaman Data Pembayaran SPP

15. Tampilan Halaman Laporan Absensi

12. Tampilan Halaman Manajemen Data Guru 


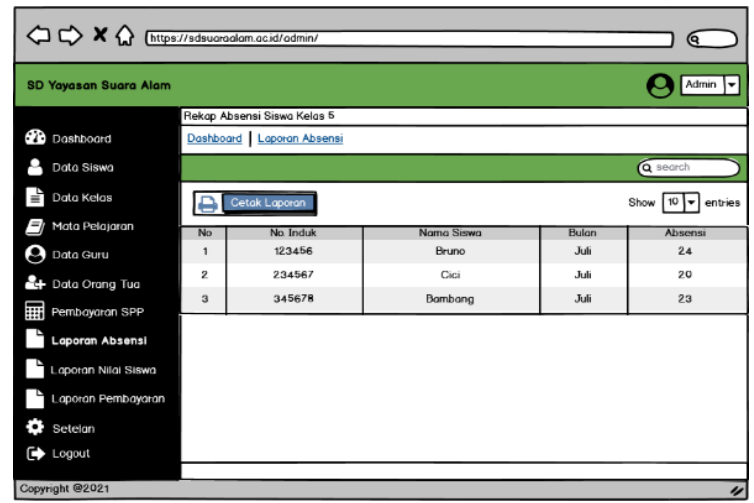

Sumber : Hasil Pengolahan (2021)

Gambar 22

Tampilan Halaman Laporan Absensi

16. Tampilan Halaman Laporan Nilai Siswa

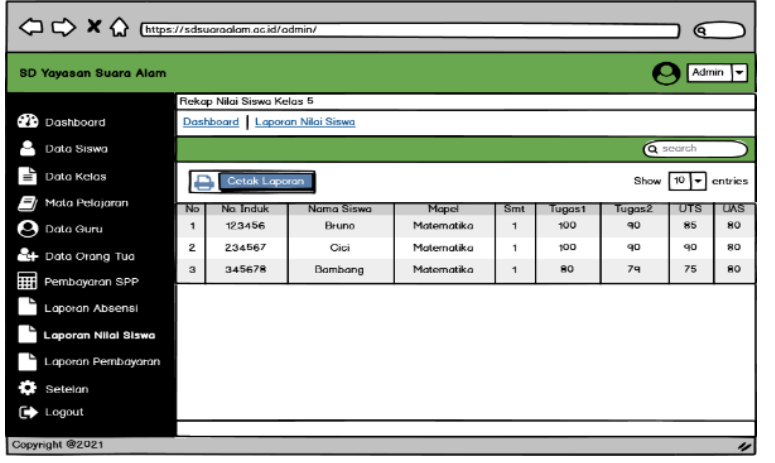

Sumber : Hasil Pengolahan (2021)

Gambar 22

Tampilan Halaman Laporan Nilai Siswa

17. Tampilan Halaman Laporan Pembayaran Siswa

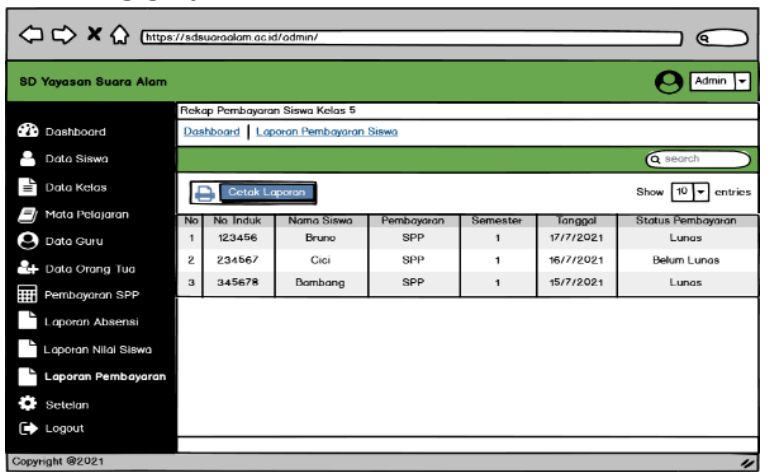

Sumber : Hasil Pengolahan (2021)

Gambar 23

Tampilan Halaman Laporan Pembayaran Siswa

18. Tampilan Halaman Setelan Admin

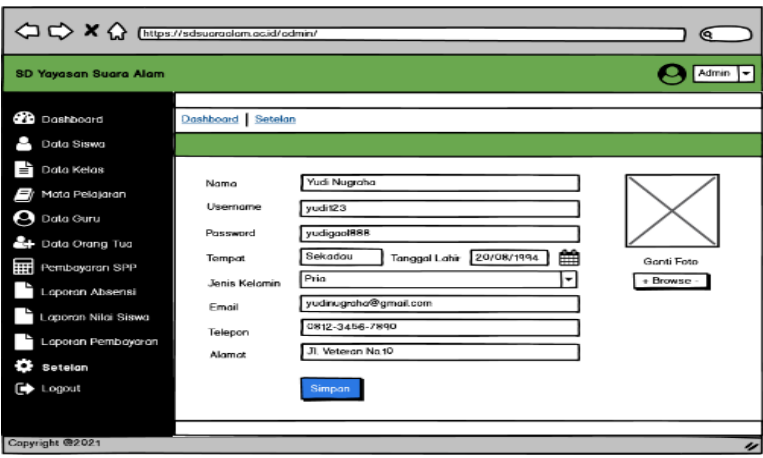

Sumber : Hasil Pengolahan (2021)

Gambar 24

Tampilan Halaman Setelan Admin

\section{KESIMPULAN}

Dari hasil rancangan sistem usulan yang sudah dibahas pada bab-bab sebelumnya, dapat ditarik kesimpulan sebagai berikut

1. Bahwasannya jika sistem informasi monitoring berbasis web ini diimplemaentasikan, diharapkan dapat membantu pihak admin, guru dan petugas tata usaha dalam pengolahan data-data penting yang terdapat di sekolah seperti masalah pengarsipan absensi, penilaian dan pembayaran siswa pada Sekolah Dasar Yayasan Suara Alam.

2. Bahwasannya jika sistem informasi ini nantinya diimplementasikan, orangtua tidak perlu susah payah untuk mendatangi SD Yayasan Suara Alam apabila ingin mengetahui perkembangan anak seperti masalah absensi, penilaian maupun pembayaran siswa. Karena informasi tersebut sudah dapat diakses melalui website.

3. Guru dan petugas Tata Usaha tidak perlu merekap data selama berbulan-bulan di dalam buku, karena data yang masuk dapat langsung dimasukan kedalam website ini sehingga dapat meminimalisir kehilangan dokumen maupun kerusakan dokumen.

4. Sistem informasi ini dirancang dengan tujuan untuk membantu proses rekap data secara otomatis mudalai dari data absensi, penilaian dan pembayaran siswa sekaligus dapat mencetak laporan absen, laporan nilai dan laporan pembayaran siswa secara otomatis

\section{REFERENSI}

Ali, M., \& Istanto. (2018). Manajemen Sekolah Islam. Surakarta: Muhammadiyah Universitiy Press.

Anha, R. (2017). Pengertian Perancangan, Konser dasar sistem, Karakteristik Sistem, Klasifikasi Sistem.

Anwar, S., \& Irawan, F. (2017). Rancang Bangun Sistem Informasi Pengajuan Pengadaan Suku Cadang Mobil Pada PT. Andalan Chrisdeco Berbasis Web. Jurnal Pilar Nusa Mandiri, $\quad$ Volume $13 . \quad$ No.1:114. https://ejournal.nusamandiri.ac.id/index.php/pilar/issue 
$\not$ view/5

Arizona, N. (2017). Aplikasi Pengolahan Data Anggaran Pendapatandan Belanja Desa (APBDES) pada Kantor Desa Bakau Kecamatan JawaiBerbasisWeb. CYBERNETICS, 107. http://openjurnal.unmuhpnk.ac.id/index.php/C $\mathrm{N} /$ article/view/745

Asmara, R. (2016). Sistem Informasi Pengolahan Data Penanggulangan BencanaPada Kantor Badan Penanggulangan Bencana Daerah (BPBD) KabupatenPadang Pariaman. Jurnal J-Click, Vol: 3, No: $2 . \quad$ ISSN : 2355-7958. http://ejurnal.jayanusa.ac.id/index.php/IClick/article/view/28

Fadjar. ( 2002). Pengenalan Nilai Budaya dan Etika Bagi Mahasiswa. Yogyakarta : Yogyakarta .

Firmansyah, Y., \& Udi. (2018). Penerapan Metode SDLC Waterfall DalamPembuatan Sistem Informasi Akademik Berbasis Web Studi Kasus Pondok Pesantren Al-Habi Sholeh Kabupaten Kubu Raya, Kalimantan Barat. Jurnal Teknologi \& Manajemen Informatika, 185-191. https://jurnal.unmer.ac.id/index.php/jtmi/articl e/view/1605

Hafizh, K. M., Budiman, E., \& Rudiman. (2017). Sistem Informasi Monitoring Nilai Siswa SDN 017 Anggana. 629.

Hidayatullah, P. (2015). Pemrograman Web. Bandung: Informatika Bandung.

Hidayatullah, P., \& Jauhari , K. K. (2017). Pemrograman WEB. Bandung: Informatika Bandung.

Kesuma, C., \& Rahmawati, L. (2017). Sistem Informasi Akademik Berbasis WebPada SMK Purnama 2 Banyumas. Indonesian Journal on Networking andSecurity, Vol 7(No 3), 1-9. https://ijns.org/journal/index.php/ijns/article/ view/1515

Mahdiati, T., \& Fridayanthie, E. W. (2016). Rancang Bangun Sistem Informasi Permintaan Atk Berbasis Intranet (Studi Kasus: Kejaksaan Negeri Rangkasbitung). Jurnal Informatika, 4(2), 126137. https://ejournal.bsi.ac.id/ejurnal/index.php/kha tulistiwa/article/view/1264

Marisa, F. (2017). Web Programming (Client Side and Server Side). Yogyakarta: Deepublish. 